\title{
Impact of successful local ablative bridging therapy prior to liver transplantation on long-term survival in patients with hepatocellular carcinoma in cirrhosis
}

\author{
Astrid Bauschke ${ }^{1}$ Annelore Altendorf-Hofmann ${ }^{1} \cdot$ Michael Ardelt $^{1} \cdot$ Herman Kissler $^{1} \cdot$ Hans-Michael Tautenhahn $^{1}$. \\ Utz Settmacher ${ }^{1}$
}

Received: 1 February 2020 / Accepted: 8 April 2020 / Published online: 30 April 2020

(c) The Author(s) 2020

\begin{abstract}
Background It has been shown that local ablative procedures enable downsizing, reduce drop-out from the waiting list and improve prognosis after liver transplantation. It is still unclear whether a response to the local ablative therapy is due to a favorable tumor biology or if a real benefit in tumor stabilization exists, particularly in complete pathological response.

Method Data of $163 \mathrm{HCC}$ patients who underwent liver transplantation were extracted from our prospectively maintained registry. We analyzed the tumor load, pre-transplant $\alpha$-fetoprotein levels, child stage aside the application and success of local ablative therapies as bridging procedures before transplantation.

Results 87 patients received multiple and/or combined local therapies. In 20 cases, this resulted in a complete remission of the tumor as observed in the explant histology. The other 76 patients underwent no bridging procedure. The observed 5- and 10-year survival rates for patients with bridging were $67 \%$ and $47 \%$ and without bridging $56 \%$ and $46 \%$, respectively. Tumor-related 10-year survival showed a statistically significant difference between both groups ( $81 \%$ versus $59 \%$ ). In the multivariate analyses bridging, number of lesions and $\alpha$-fetoprotein level showed an independent statistically significant influence on tumor-related survival in these patients.

Conclusions Successful local ablative therapy before liver transplantation is an independent statistically significant factor in long-term tumor-related survival for patients with HCC in cirrhosis and reduces tumor recurrences.
\end{abstract}

Keywords Bridging therapy $\cdot \mathrm{HCC} \cdot$ Liver transplantation $\cdot$ Long term survival

\section{Introduction}

Transarterial chemoembolization (TACE), radio frequency ablation (RFA), radioembolization (RE), percutaneous alcohol injection (PEI), microwave ablation, irreversible electroporation and stereotactic body radiation therapy (SBRT) in combination with thyrosinkinase inhibitor are being employed for local ablative treatment prior to liver transplantation (LT) in selected patients [1-7]. TACE is the most frequently employed bridging procedure. The role of bridging therapy was first reported by Manjo et al. in a study of

Astrid Bauschke

astrid.bauschke@med.uni-jena.de

1 Department of General, Visceral and Vascular Surgery, University Hospital Jena, Erlanger Allee 101, 07740 Jena, Germany the Hospital Paul Brousse, Villejuif, France [8]. The procedures are often combined and/or repeated for increased efficiency [9]. It has been shown that local ablative procedures enable downsizing, reduce drop-out from the waiting list and improve prognosis after liver transplantation [5, 10-14]. A statistically significant improvement of survival has been documented in a multi-center study of the European Liver Transplant Registry (Pommergard 2018). It is still unclear whether a response to the local ablative therapy is due to a favorable tumor biology or if a real benefit in tumor stabilization exists, particularly in complete pathological response.

Here, we present the effect of local ablative bridging procedures on the 10-year recurrence rate and the tumor-related 10-year survival after liver transplantation for HCC in our patient population. To the best of our knowledge, this is the first long-term observation in this field. 


\section{Materials and methods}

From our prospectively maintained tumor register, we extracted data of HCC patients who underwent liver transplantation between 1996 and 2017. Patients who died within 3 months after LT and patients transplanted for recurrence of HCC after partial hepatectomy were excluded. All patients were followed-up until death or until August, 1st 2018. 163 patients were included in the study.

In cases of sufficient liver function bridging procedures, such as liver resection, local ablative procedures (transarterial chemoembolization (TACE), radio frequency ablation (RFA), Yttrium ${ }^{90}$ radio embolization ( $\left.\mathrm{Y}^{90} \mathrm{RE}\right)$, tomotherapy, in combination with systemic therapy with thyrosinkinase inhibitor were employed since 2004. All these interventions were continued for as long as residual tumor was identified and monitored radiologically in 90 days intervals. In cases of residual vital tumor, the procedures were repeated and combined. TACE was the most frequently applied local ablative therapy. In 87 patients $(54 \%)$, TACE, RFA or $\mathrm{Y}^{90}$ radioembolisation was performed, some of them repeatedly. 67, 13 and 7 cases, respectively, (77\%, 15\%, und 8\%) were TACE, RFA or $\mathrm{Y}^{90}$ radioembolisation. 79 patients did not receive any bridging therapy (transplantation before 2004, or functionally unsuitable for local ablative procedures).

133 patients received a deceased donor liver. 30 patients received a split from a living donor (all of them received segments SV-VIII). The waiting time prior to living donation was median 6 months (range 0-20 months) and, thus statistically significantly shorter than prior to deceased donor transplantation (median 9 months, range 0-46). mTOR-based long-term immunosuppression was administered since 2010 in patients who had no contraindications.

Follow-up consultations after LT for HCC are standardized including follow-up for tumor status. As long as laboratory tests including AFP were within normal ranges, a CT scan was performed every 3 months for the first 2 years and then annually. If tumor recurrence was confirmed, therapeutic options were discussed in the interdisciplinary hepatobiliary tumor board. We performed surgical resections with curative intent for intra- and extra-hepatic recurrence, applied local therapy (TACE, $\left.\mathrm{Y}^{90} \mathrm{RE}, \mathrm{RFA}\right)$ in non-resectable intra-hepatic recurrences and radiation for bone metastases. Whenever possible, a systemic therapy with thyrosinkinase inhibitors followed.

We analyzed the morphological data of the tumor load in pre-transplant contrast computed tomography (CT) or magnetic resonance imaging (MRI) scans, $\alpha$-fetoprotein (AFP) (ng/ml) level, stage of underlying liver disease (Child stage) and use of loco-regional therapy.

All patients gave their consent for clinical registration. We have only used data from the clinical data registry. The study in humans has been carried out with approval of the local ethics committee (Nr. 4337-02/15), in accordance with national law and the Declaration of Helsinki of 1975 (in the current revised form).

The statistical univariate analysis was performed with SPSS Software version 19. Differences in the distribution of variables have been tested with Fisher's exact test or with Chi square test for statistically significant differences. Survival rates were calculated with the Kaplan-Meier procedure and significance testing was performed with the log-rank test. Starting point for survival was date of transplantation. End point for observed and tumor-related survival were death of any cause and death of hepatocellular carcinoma, respectively. Cox regression analysis was used for the multivariate analysis.

\section{Results}

Patient age at transplantation was median 61 years (range 38-72 years). Morphological tumor load was ,inside Milan“ in $70(43 \%)$ patients and ,outside Milan“ in $93(57 \%)$ patients. Further data on patients and tumor load are being shown in Table 1. Child- and UICC stage were different in patients with and without bridging. Bridging resulted in complete remission (no evidence of vital tumor tissue in the explant specimen) in 20 cases. This was most frequently observed in single lesions $(13 / 42=31 \%$ vs. $7 / 45=16 \%)$ and after RFA $(5 / 10$ vs. $15 / 77=20 \%)$, respectively.

Median follow-up time after LT was 55 months (range 8-264). By now, 71 patients died, 34 of them of other causes and $37(22 \%)$ of them from $\mathrm{HCC}$ recurrence. 5 patients died from malignant second tumor (lung cancer in 3, pancreatic cancer in one and urinary bladder cancer in one), and 29 died from other causes.

Of the 92 living patients, 10 developed a second carcinoma after LT (3 each in the ENT area or on the skin, one each B-cell lymphoma, stomach GIST, small cell renal carcinoma or prostate cancer).

Observed 5- and 10-year survival rates were $62 \%$ and $47 \%$, respectively. Observed 5-year survival rate was higher with bridging than without (67\% vs. $56 \%)$. The difference did not reach statistical significance, though. The respective 10 -year survival rates were $47 \%$ and $46 \%$, respectively. For tumor-related survival, there was a statistically significant difference in long-term survival (Fig. 1). In addition to bridging, tumor-related survival was statistically significantly related by the level of pre-operative $\alpha$-fetoprotein levels, Milan and UICC classification (Table 2, Fig. 2).

Sex, patient age, type of bridging procedure, existing portal vein thrombosis and child stage had no statistically significant influence on tumor-related 10-year survival in the univariate analysis. 
Table 1 Patients under study

\begin{tabular}{|c|c|c|c|c|c|c|}
\hline \multirow[t]{3}{*}{ Item } & \multirow[t]{3}{*}{ Total } & \multicolumn{4}{|c|}{ Bridging } & \multirow[t]{3}{*}{$P$} \\
\hline & & \multicolumn{2}{|c|}{$\overline{\text { No }}$} & \multicolumn{2}{|l|}{ Yes } & \\
\hline & & $\bar{n}$ & $\%$ & $n$ & $\%$ & \\
\hline Total & 163 & 76 & & 87 & & - \\
\hline \multicolumn{7}{|l|}{ Sex } \\
\hline Male & 135 & 63 & 46.7 & 72 & 53.3 & $\mathrm{~ns}$ \\
\hline Female & 28 & 13 & 46.4 & 15 & 53.6 & \\
\hline \multicolumn{7}{|l|}{ Age } \\
\hline$<60$ years & 81 & 42 & 51.9 & 39 & 48.1 & $\mathrm{~ns}$ \\
\hline$\geq 60$ years & 82 & 34 & 41.5 & 48 & 58.5 & \\
\hline \multicolumn{7}{|l|}{ Child stage } \\
\hline Other & 16 & 11 & 68.8 & 5 & 31.3 & 0.009 \\
\hline Child A & 64 & 23 & 35.9 & 41 & 64.1 & \\
\hline Child B & 55 & 23 & 41.8 & 32 & 58.2 & \\
\hline Child C & 28 & 19 & 67.9 & 9 & 32.1 & \\
\hline \multicolumn{7}{|l|}{ Underlying liver disease } \\
\hline Other & 18 & 11 & 61.1 & 7 & 38.9 & $\mathrm{~ns}$ \\
\hline Alcoholic & 92 & 39 & 42.4 & 53 & 57.6 & \\
\hline Hepatitis & 41 & 19 & 46.3 & 22 & 53.7 & \\
\hline Cryptogenic & 12 & 7 & 58.3 & 5 & 41.7 & \\
\hline \multicolumn{7}{|l|}{ Number of lesions } \\
\hline 1 lesion & 83 & 42 & 50.6 & 41 & 49.4 & ns \\
\hline 2-3 lesions & 37 & 14 & 37.8 & 23 & 62.2 & \\
\hline$\geq 4$ lesions & 43 & 20 & 46.5 & 23 & 53.5 & \\
\hline \multicolumn{7}{|l|}{ Multiplicity } \\
\hline Solitary & 85 & 43 & 50.6 & 42 & 49.4 & ns \\
\hline Multiple & 78 & 33 & 42.3 & 45 & 57.7 & \\
\hline \multicolumn{7}{|c|}{ Diameter of lesions (Maximum) } \\
\hline$<5 \mathrm{~cm}$ & 94 & 41 & 43.6 & 53 & 56.4 & ns \\
\hline$\geq 5 \mathrm{~cm}$ & 69 & 35 & 50.7 & 34 & 49.3 & \\
\hline \multicolumn{7}{|l|}{$\alpha$-Fetoprotein $(\mathrm{ng} / \mathrm{ml})^{\mathrm{b}}$} \\
\hline$<35$ ng/ml (normal) & 109 & 47 & 43.1 & 62 & 56.9 & ns \\
\hline$\geq 35 \mathrm{ng} / \mathrm{ml}$ (elevated) & 46 & 27 & 58.7 & 19 & 41.3 & \\
\hline$<400 \mathrm{ng} / \mathrm{ml}$ & 141 & 66 & 89.2 & 75 & 92.6 & $\mathrm{~ns}$ \\
\hline$\geq 400 \mathrm{ng} / \mathrm{ml}$ & 14 & 8 & 10.8 & 6 & 7.4 & \\
\hline \multicolumn{7}{|l|}{ Portal vein thrombosis ${ }^{\mathrm{a}}$} \\
\hline No & 148 & 68 & 45.9 & 80 & 54.1 & $\mathrm{~ns}$ \\
\hline Yes & 15 & 8 & 53.3 & 7 & 46.7 & \\
\hline \multicolumn{7}{|l|}{ Extent of hepatic tumor } \\
\hline Solitary, $\leq 50 \%$ & 83 & 41 & 49.4 & 42 & 50.6 & ns \\
\hline Multiple, $\leq 50 \%$ & 58 & 23 & 39.7 & 35 & 60.3 & \\
\hline$>50 \%$ & 22 & 12 & 54.5 & 10 & 45.5 & \\
\hline \multicolumn{7}{|l|}{ Milan } \\
\hline Milan in & 70 & 33 & 47.1 & 37 & 52.9 & ns \\
\hline Milan out & 93 & 43 & 46.2 & 50 & 53.8 & \\
\hline \multicolumn{7}{|l|}{ UCSF } \\
\hline UCSF in & 87 & 38 & 50.0 & 49 & 56.3 & ns \\
\hline UCSF out & 76 & 38 & 50.0 & 38 & 43.7 & \\
\hline \multicolumn{7}{|l|}{ UICC stage $^{c}$} \\
\hline Stage I/II & 100 & 47 & 47.0 & 53 & 53.0 & 0.029 \\
\hline Stage III/IV & 43 & 29 & 67.4 & 14 & 32.6 & \\
\hline
\end{tabular}

$n s$ no statistically significant difference

${ }^{a}$ No macrovascular invasion

b8 missing

c20 missing 


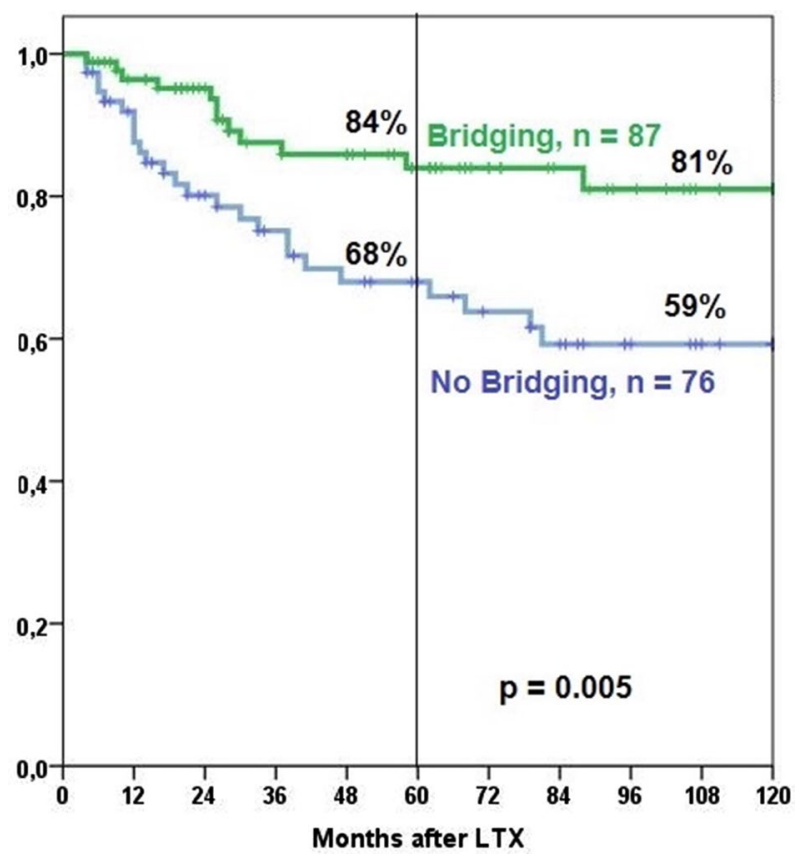

Fig. 1 Tumor-related survival of patients with versus without bridging therapy
The statistically significant influence of bridging was maintained with stratification according to Milan classification (Fig. 2).

Of the 20 patients with complete pathological response after bridging, none has died from tumor recurrence so far. $12 / 20$ had been histologically confirmed pre-LT, the others were classified as HCC from CT/MRT scans and AFP.

Bridging therapy, level of pre-operative $\alpha$-fetoprotein and number of lesions showed an independent statistically significant impact on tumor-free survival in the multivariate analysis (Table 3).

\section{Recurrence}

46 patients $(28 \%)$ developed a tumor recurrence. 13 recurrences were located intra-hepatically. Of the 33 extra-hepatic recurrences lung, bones, adrenal glands and peritoneum were affected in 12, 9, 5, 4 patients; abdominal wall, thoracic wall and pericardium were affected in one each.

Following LT with prior bridging, one patient developed an intra-hepatic recurrence, 16 patients (18\%) developed extra-hepatic recurrence. Without prior bridging, intrahepatic recurrence was observed in 12 patients (16\%), extra-hepatic recurrence in 17 patients $(22 \%)$. The rates of
Fig. 2 Tumor-related survival of patients with versus without bridging therapy stratified according to Milan criteria

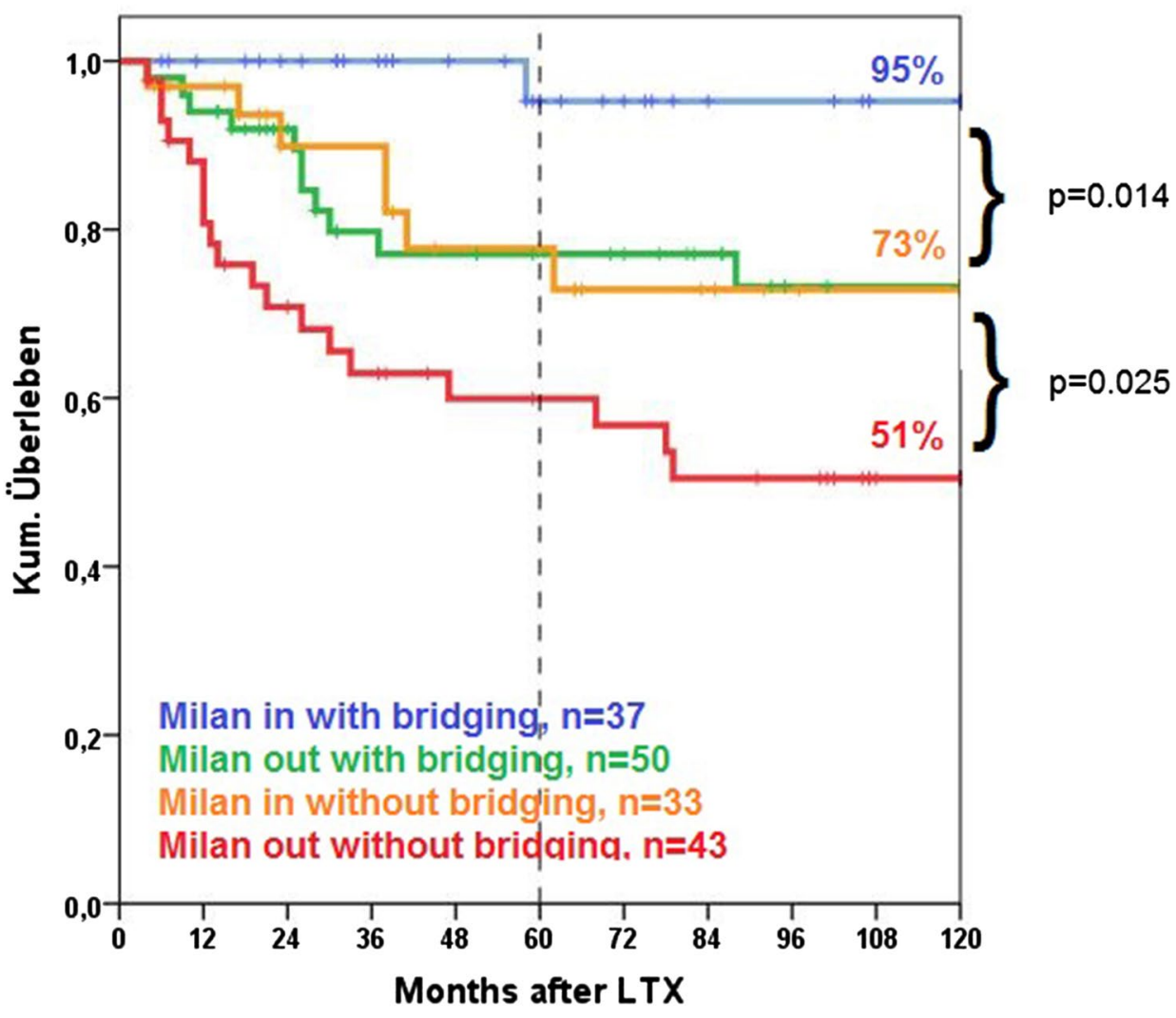


Table 2 Univariat 10-year tumor related survival

\begin{tabular}{llll}
\hline Item & $\mathrm{n}$ & $\%$ & $p$ \\
\hline $\begin{array}{l}\text { Total } \\
\text { Multiplicity }\end{array}$ & 163 & $70 \pm 4$ & - \\
$\quad$ Solitary & 85 & $82 \pm 5$ & 0.002 \\
$\quad$ Multiple & 78 & $57 \pm 7$ & \\
$\alpha$-Fetoprotein (ng/ml) ${ }^{* 1}$ & & & \\
$\quad<35 \mathrm{ng} / \mathrm{ml}$ (normal) & 109 & $76 \pm 5$ & 0.014 \\
$\geq 35 \mathrm{ng} / \mathrm{ml}$ (elevated) & 46 & $61 \pm 8$ & \\
Milan & & & \\
$\quad$ Milan in & 70 & $61 \pm 6$ & 0.003 \\
$\quad$ Milan out & 93 & $69 \pm 5$ & \\
UICC stage & & & \\
$\quad$ stage I/II & 120 & $81 \pm 4$ & $<0.001$ \\
$\quad$ stage III/IV & 43 & $44 \pm 9$ & \\
Bridging & & & \\
$\quad$ yes & 76 & $81 \pm 5$ & 0.005 \\
no & 87 & $59 \pm 7$ & \\
\hline
\end{tabular}

${ }^{* 1} 8$ missing

Table 3 Multivariate 10-year tumor related survival

\begin{tabular}{llll}
\hline & $\mathrm{p}$ & Hazard & $\begin{array}{l}95,0 \% \\
\text { confidence } \\
\text { interval }\end{array}$ \\
\hline Bridging & 0.010 & 2562 & $1249-5257$ \\
Multiplicity & 0.001 & 3207 & $1575-6531$ \\
$\alpha$-Fetoprotein (ng/ml) & 0.007 & 2519 & $1284-4944$ \\
\hline
\end{tabular}

intra-hepatic recurrence were statistically significantly different $(p=0.001)$.

Duration of recurrence diagnosis from LT was median 12 months (range 2-62). Where possible, recurrences were treated with curative intent. In cases of intra-hepatic recurrence (IHR), patients survived for median 2 months and in cases of extra-hepatic recurrence (EHR) 18 months. Patients treated with curative intent survived the recurrence for median 38 months, patients treated with palliative intent 6 months.

\section{Discussion}

To our best knowledge, this is the first monocentric series that shows a statistically independent influence of bridging therapy on tumor-related 10-year survival after liver transplantation in patients with HCC in cirrhosis. In patients with bridging therapy, the rate of intra-hepatic recurrence decreased from 16 to $1 \%$, but the rate of extra-hepatic recurrence was unchanged. 20 patients had a complete pathological response. None of them died of recurrence as yet. Only transplanted patients were enrolled in the study. The majority of patients which were removed from the transplant waiting list had distant metastases or intra-hepatic tumor progress. Rarely, patients were removed from the list for other reasons, like aggravation of comorbidities, noncompliance or newly diagnosed second primary tumors. If liver function was sufficient, loco-regional ablative therapy was carried out in these patients. Unfortunately, these data are missing due the retrospective data analysis.

EASL/EORTC guidelines and the international consensus conference for liver transplantation for hepatocellular carcinoma recommend bridging therapy if the waiting time exceeds 6 months $[15,16]$. The American guidelines from the AASLD states bridging therapy as the method to prevent tumor progression and drop out from the waiting list [17].

Studies on bridging therapies are extremely heterogenous. There are no recommendations concerning indications for the different procedures, choice of procedure in remaining vital tumor tissue as well as documentation and quality assurance of local ablative therapies. The choice of procedures often depends on local availability. Thus, comparability and reporting the results of these procedures are extremely difficult. In the literature as well as in our study, TACE was the most frequently employed bridging procedure. Currently, there are only small case series on ${ }^{90} \mathrm{Y} R E$ as successful bridging therapy prior to transplantation [6, 18-21]. Prospective randomized studies are missing, thus an evaluation of the ${ }^{90} \mathrm{Y} R E$ is not possible to date. In selected patients with a maximum of three tumor lesions, each with a maximum diameter of $3 \mathrm{~cm}$, RFA can be performed safely and effectively. Also, the large proportion of complete histological tumor absence in 7/13 patients treated with RFA in our study results from the limited tumor burden.

Primary tumor size and number of lesions vary (Yao und Fidelman 2016; [22]). In our series, transplantation was performed in 93/163 patients with HCC “outside Milan". The efficiency of bridging therapy in large tumors for meeting the Milan criteria was reported [22, 23]. In our series, too, the effect of bridging in small and large tumor burden was observed.

\section{Short-term effect of bridging}

Numerous studies on bridging prior to LT evaluate the success from imaging studies, employing different standards for remission. Successful radiological criteria of downstaging are tumor shrinkage by 30 or $50 \%[5,24]$, meeting the Milan criteria $[6,25,26]$, meeting the Milan criteria with definition of AFP target levels [22, 27], meeting the UCSF criteria [23] as well as complete or partial response according to the mRECIST criteria [28]. The pathological report of the explanted liver for evaluation of response behavior 
Table 4 Pathological response after bridging therapy

\begin{tabular}{lccll}
\hline & Time period & $\begin{array}{l}\text { Number of Patient } \\
\text { with Bridging } \\
\text { therapy }\end{array}$ & $\begin{array}{l}\text { Path } \\
\text { complete } \\
\text { remission }\end{array}$ & Type of bridging \\
\hline Mazzaferro et al. (2004) & $1998-2003$ & 50 & $54 \%$ & RFA \\
Mannina et al. (2017) & $2008-2015$ & 38 & $53 \%$ & SBRT \\
El-Gazzaz et al. (2013) & $2002-2011$ & 128 & $39 \%$ & DEB-TACE, RE, RFA \\
Barakat et al. (2010) & $2003-2006$ & 14 & $38 \%$ & TACE, RFA, RE \\
Rubinstein et al. (2017) & $2009-2014$ & 50 & $30 \%$ & TACE, RFA, MW, RE \\
Moore et al. (2017) & $2011-2016$ & 23 & $27 \%$ & SBRT \\
Bargellini et al. (2010) & $1997-2006$ & 33 & $10 \%$ & TACE \\
Radunz et al. (2017) & $2007-2015$ & 40 & $42 \%$ & RE \\
Seehofer et al. (2012) & $1989-2008$ & 71 & $18 \%$ & TACE \\
Agopian et al. (2015) & $1994-2013$ & 501 & $25 \%$ & TACE, RFA, PEI \\
Na et al. (2016) & $2003-2012$ & 52 & $49 \%$ & TACE, RFA, PEI \\
Own data & $1996-2017$ & 87 & $23 \%$ & DEB-TACE, RFA, RE, SBRT \\
\hline
\end{tabular}

$T A C E$ transarterial chemoembolisation, DEB-TACE drug-eluting beads“ transarterial chemoembolisation, $R E$ radioembolisation, $R F A$ radio frequency ablation, $S B R T$ stereotactic Body Radiation Therapy, $M W$ microwave ablatio is used only in some studies in addition to imaging studies after bridging. Shaker et al. have shown that radiological response was more pronounced than pathological evaluation of response from the explant specimen [29].

In the literature, information on complete pathological response after bridging therapy ranges from 10 to $54 \%$ in different procedures. In our patients, we saw complete pathological response after bridging in 20 of 87 patients (23\%) (Table 4).

The efficiency of local ablative therapy has been documented by various radiological studies [30, 31]. Lei et al. reported superior overall survival and tumor-free survival in the group of responders (patients with response (mRECIST) after local ablative therapy with TACE). In particular, the long-term results of patients with HCC outside Milan were after TACE with response better $(p<0.05)$. In the univariate analysis as well as in the multivariate analysis, complete and partial response after TACE was the best predictor for survival and tumor-free survival [32]. Discrepancies of $25 \%$ between radiological and pathological response have been reported [33]. Thus, there is an uncertainty to date.

Other factors, such as waiting time for the donor organ or immunosuppression may influence the recurrence rate after liver transplantation [34-36].

\section{Long-term effect of bridging}

Few studies address the impact of bridging therapy on longterm survival. Here, too, different target criteria are being used (overall survival, disease specific survival, recurrence rate). The observed 5-year survival in patients with bridging therapy prior to transplantation for HCC in cirrhosis ranges from 55 to $94 \%$ in the literature $[25,37$ ] Only Lee et al. reported 10 -year survival of $42 \%$ with bridging therapy [38].

The significant impact of tumor number on long-term survival in our series has also been documented by Pawlik et al. and Llovet et al. [39, 40]. Na et al. and Jang et al. reported in agreement with our series a statistically significant impact

Table 5 Literature references on impact of bridging therapy on long term survival OS overall survival, RFS recurrence free survival, DSS disease specific survival

\begin{tabular}{|c|c|c|c|c|c|}
\hline & Time period & Patients w/o bridging & $\begin{array}{l}\text { Median follow } \\
\text { up mo. }\end{array}$ & 5 year survival w/o bridging & $p$ \\
\hline Majno et al. (1997) & 1985-1995 & $54 / 57$ & 40 & RFS: $57 \% / 59 \%$ & n.s. \\
\hline Seehofer et al. (2012) & 1989-2008 & $71 / 106$ & - & OS: $73 \% / 69 \%$ & n.s. \\
\hline Agopian et al. (2017)* & 2002-2013 & $2754 / 747$ & 46,7 & RFS: $68 \% / 68 \%$ & n.s. \\
\hline Pommergaard et al. (2018)* & 1990-2016 & $4978 / 23124$ & 26 & OS: $69,7 \% / 65,8 \%$ & $<0.001$ \\
\hline Jena 2019 & 1996-2017 & $87 / 76$ & 55 & $\begin{array}{l}\text { OS: } 67 \pm 5 \% / 56 \pm 5 \% \text { DSS: } 84 \% \\
\pm 5 \% / 81 \% \pm 5 \%\end{array}$ & n.s. \\
\hline
\end{tabular}

OS overall survival, RFS recurrence free survival, DSS disease specific survival

*multicentric 
of AFP levels on long-term survival [37, 41]. Agopian et al. reported a significant impact of AFP on the long-term results in correlation to response to bridging therapy [42]. Comparative studies between patients with and without bridging therapy are listed in Table 5. In the European register study of Pommergraad et al., there was a statistically significant difference in survival of patients transplanted for HCC with versus without bridging therapy [14]. In the other studies, no statistically significant difference was reported. 10-year survival rates have been reported by Seehofer et al. only, according to our knowledge (Table 5).

\section{Summary}

To reduce prognostically relevant recurrence after LT different options are being investigated. In our series, response behavior to bridging therapy prior to transplantation for HCC in the explanted liver had a positive impact on longterm survival, cumulative tumor recurrence rate and location of tumor recurrence after LT.

\section{Lay summary}

We report on a single-center analysis of all local ablative bridging procedures (TACE, RFA, RE, PEI) prior to liver transplantation with 10-year long-term survival.

Acknowledgements Open Access funding provided by Projekt DEAL.

\section{Compliance with ethical standards}

Conflict of interest The authors declare that they have no competing interests.

Ethical approval The study in humans has been carried out with approval of the local ethics committee (Nr. 4337-02/15), in accordance with national law and the Declaration of Helsinki of 1975 (in the current revised form). Informed consent: All patients give their consent for clinical registration. We have only used data from the clinical data registry.

Open Access This article is licensed under a Creative Commons Attribution 4.0 International License, which permits use, sharing, adaptation, distribution and reproduction in any medium or format, as long as you give appropriate credit to the original author(s) and the source, provide a link to the Creative Commons licence, and indicate if changes were made. The images or other third party material in this article are included in the article's Creative Commons licence, unless indicated otherwise in a credit line to the material. If material is not included in the article's Creative Commons licence and your intended use is not permitted by statutory regulation or exceeds the permitted use, you will need to obtain permission directly from the copyright holder. To view a copy of this licence, visit http://creativecommons.org/licenses/by/4.0/.

\section{References}

Agopian VG, Morshedi MM, McWilliams J, Harlander-Locke MP, Markovic D, Zarrinpar A et al (2015) Complete pathologic response to pretransplant locoregional therapy for hepatocellular carcinoma defines cancer cure after liver transplantation: analysis of 501 consecutively treated patients. Ann Surg 262(3):536-545 (discussion 43-5)

Agopian VG, Harlander-Locke MP, Ruiz RM, Klintmalm GB, Senguttuvan S, Florman SS et al (2017) Impact of pretransplant bridging locoregional therapy for patients with hepatocellular carcinoma within milan criteria undergoing liver transplantation: analysis of 3601 patients from the US Multicenter HCC transplant consortium. Ann Surg 266(3):525-535

Barakat O, Wood RP, Ozaki CF, Ankoma-Sey V, Galati J, Skolkin M et al (2010) Morphological features of advanced hepatocellular carcinoma as a predictor ofdownstaging and liver transplantation: an intention-to-treat analysis. Liver Transpl 16(3):289-299

Bauschke A, Altendorf-Hofmann A, Freesmeyer M, Winkens T, Malessa C, Schierz JH et al (2016) Selective internal radioembolization in nonresectable hepatocellular carcinoma. Der Chirurg, Zeitschrift fur alle Gebiete der operativen Medizen

Bova V, Miraglia R, Maruzzelli L, Vizzini GB, Luca A (2013) Predictive factors of downstaging of hepatocellular carcinoma beyond the Milan criteria treated with intra-arterial therapies. Cardiovasc Intervent Radiol 36(2):433-439

Carr BI (2004) Hepatic arterial 90Yttrium glass microspheres (Therasphere) for unresectable hepatocellular carcinoma: interim safety and survival data on 65 patients. Liver Transplant 10(2 Suppl 1):S107-S110

Chapman WC, Majella Doyle MB, Stuart JE, Vachharajani N, Crippin JS, Anderson CD et al (2008) Outcomes of neoadjuvant transarterial chemoembolization to downstage hepatocellular carcinoma before liver transplantation. Ann Surg 248(4):617-625

Clavien PA, Lesurtel M, Bossuyt PM, Gores GJ, Langer B, Perrier A (2012a) Recommendations for liver transplantation for hepatocellular carcinoma: an international consensus conference report. Lancet Oncol 13(1):e11-22

Clavien PA, Lesurtel M, Bossuyt PM, Gores GJ, Langer B, Perrier A et al (2012b) Recommendations for liver transplantation for hepatocellular carcinoma: an international consensus conference report. Lancet Oncol 13(1):e11-22

El-Gazzaz G, Sourianarayanane A, Menon KV, Sanabria J, Hashimoto K, Quintini C et al (2013) Radiologic-histological correlation of hepatocellular carcinoma treated via pre-liver transplant locoregional therapies. Hepatobiliary Pancreat Dis Int. 12(1):34-41

De Luna W, Sze DY, Ahmed A, Ha BY, Ayoub W, Keeffe EB et al (2009) Transarterial chemoinfusion for hepatocellular carcinoma as downstaging therapy and a bridge toward liver transplantation. Am J Transplant 9(5):1158-1168

Gordon-Weeks AN, Snaith A, Petrinic T, Friend PJ, Burls A, Silva MA (2011) Systematic review of outcome of downstaging hepatocellular cancer before liver transplantation in patients outside the Milan criteria. Br J Surg 98(9): 1201-1208

Graziadei IW, Sandmueller H, Waldenberger P, Koenigsrainer A, Nachbaur K, Jaschke W et al (2003) Chemoembolization followed by liver transplantation for hepatocellular carcinoma impedes tumor progression while on the waiting list and leads to excellent outcome. Liver Transplant 9(6):557-563 
Heimbach JK, Kulik LM, Finn R, Sirlin CB, Abecassis M, Roberts LR, et al. Aasld guidelines for the treatment of hepatocellular carcinoma. Hepatology. 2017.

Jang JW, You CR, Kim CW, Bae SH, Yoon SK, Yoo YK et al (2010) Benefit of downsizing hepatocellular carcinoma in a liver transplant population. Aliment Pharmacol Ther 31(3):415-423

Kneteman N, Livraghi T, Madoff D, de Santibanez E, Kew M (2011) Tools for monitoring patients with hepatocellular carcinoma on the waiting list and after liver transplantation. Liver Transplant 17(Suppl 2):S117-S127

Kulik LM, Carr BI, Mulcahy MF, Lewandowski RJ, Atassi B, Ryu RK et al (2008) Safety and efficacy of 90Y radiotherapy for hepatocellular carcinoma with and without portal vein thrombosis. Hepatology 47(1):71-81

Kulik L, Heimbach JK, Zaiem F, Almasri J, Prokop LJ, Wang Z et al (2018) Therapies for patients with hepatocellular carcinoma awaiting liver transplantation: a systematic review and meta-analysis. Hepatology 67(1):381-400

Lai Q, Nicolini D, Inostroza Nunez M, Iesari S, Goffette P, Agostini A et al (2016) A novel prognostic index in patients with hepatocellular cancer waiting for liver transplantation: time-radiologicalresponse-alpha-fetoprotein-inflammation (TRAIN) score. Ann Surg 264(5):787-796

Lai Q, Di Martino M, Lucatelli P, Mennini G (2018) Locoregional therapy response in patients with hepatocellular cancer waiting for liver transplantation: only selection or biological effect? World J Gastroenterol 24(31):3469-3471

Lee MW, Raman SS, Asvadi NH, Siripongsakun S, Hicks RM, Chen J et al (2017) Radiofrequency ablation of hepatocellular carcinoma as bridge therapy to liver transplantation: a 10-year intention-totreat analysis. Hepatology 65(6):1979-1990

Lei J, Zhong J, Luo Y, Yan L, Zhu J, Wang W et al (2017) Response to transarterial chemoembolization may serve as selection criteria for hepatocellular carcinoma liver transplantation. Oncotarget 8(53):91328-91342

Lerut J, Iesari S, Foguenne M, Lai Q (2017) Hepatocellular cancer and recurrence after liver transplantation: what about the impact of immunosuppression? Transl Gastroenterol Hepatol 2:80

Lewandowski RJ, Kulik LM, Riaz A, Senthilnathan S, Mulcahy MF, Ryu RK et al (2009) A comparative analysis of transarterial downstaging for hepatocellular carcinoma: chemoembolization versus radioembolization. Am J Transplant 9(8):1920-1928

Llovet JM, Schwartz M, Mazzaferro V (2005) Resection and liver transplantation for hepatocellular carcinoma. Semin Liver Dis 25(2):181-200

Llovet JM, Lencioni R, Di Bisceglie AM, Gaile PR, Dufour JF, Greten TF et al (2012) EASL-EORTC clinical practice guidelines: management of hepatocellular carcinoma. J Hepatol 56(4):908-943

Majno PE, Adam R, Bismuth H, Castaing D, Ariche A, Krissat J et al (1997) Influence of preoperative transarterial lipiodol chemoembolization on resection and transplantation for hepatocellular carcinoma in patients with cirrhosis. Ann Surg 226(6):688-701

Mannina EM, Cardenes HR, Lasley FD, Goodman B, Zook J, Althouse $S$ et al (2017) Role of stereotactic body radiation therapy before orthotopic liver transplantation: retrospective evaluation of pathologic response and outcomes. Int J Radiat Oncol Biol Phys. 97(5):931-938

Mazloom A, Hezel AF, Katz AW (2014) Stereotactic body radiation therapy as a bridge to transplantation and for recurrent disease in the transplanted liver of a patient with hepatocellular carcinoma. Case Rep Oncol 7(1):18-22

Mazzaferro V, Battiston C, Perrone S, Pulvirenti A, Regalia E, Romito $\mathrm{R}$ et al (2004) Radiofrequency ablation of small hepatocellular carcinoma in cirrhotic patients awaiting liver transplantation: a prospective study. Ann Surg 240(5):900-909
Millonig G, Graziadei IW, Freund MC, Jaschke W, Stadlmann S, Ladurner R et al (2007) Response to preoperative chemoembolization correlates with outcome after liver transplantation in patients with hepatocellular carcinoma. Liver Transplant 13(2):272-279

Mohamed M, Katz AW, Tejani MA, Sharma AK, Kashyap R, Noel MS et al (2016) Comparison of outcomes between SBRT, yttrium-90 radioembolization, transarterial chemoembolization, and radiofrequency ablation as bridge to transplant for hepatocellular carcinoma. Adv Radiat Oncol 1(1):35-42

Moore A, Cohen-Naftaly M, Tobar A, Kundel Y, Benjaminov O, Braun $\mathrm{M}$ et al (2017) Stereotactic body radiation therapy (SBRT) for definitive treatment and as a bridge to liver transplantation in early stage inoperable Hepatocellular carcinoma. Radiat Oncol. 12(1):163

Na GH, Kim EY, Hong TH, You YK, Kim DG (2016) Effects of loco regional treatments before living donor liver transplantation on overall survival and recurrence-free survival in South Korean patients with hepatocellular carcinoma. HPB 18(1):98-106

Ni JY, Liu SS, Xu LF, Sun HL, Chen YT (2013) Meta-analysis of radiofrequency ablation in combination with transarterial chemoembolization for hepatocellular carcinoma. World J Gastroenterol 19(24):3872-3882

Otto G, Herber S, Heise M, Lohse AW, Monch C, Bittinger F et al (2006) Response to transarterial chemoembolization as a biological selection criterion for liver transplantation in hepatocellular carcinoma. Liver Transplant 12(8):1260-1267

Pawlik TM, Delman KA, Vauthey JN, Nagorney DM, Ng IO, Ikai I et al (2005) Tumor size predicts vascular invasion and histologic grade: Implications for selection of surgical treatment for hepatocellular carcinoma. Liver Transplant 11(9):1086-1092

Pommergaard HC, Rostved AA, Adam R, Thygesen LC, Salizzoni M, Gomez Bravo MA et al (2018) Locoregional treatments before liver transplantation for hepatocellular carcinoma: a study from the European Liver Transplant Registry. Transplant Int 31(5):531-539

Radunz S, Treckmann J, Baba HA, Best J, Muller S, Theysohn JM et al (2017) Long-term outcome after liver transplantation for hepatocellular carcinoma following yttrium-90 radioembolization bridging treatment. Ann Transplant 22:215-221

Ravaioli M, Grazi GL, Piscaglia F, Trevisani F, Cescon M, Ercolani G et al (2008) Liver transplantation for hepatocellular carcinoma: results of down-staging in patients initially outside the Milan selection criteria. Am J Transplant 8(12):2547-2557

Rubinstein MM, Kaubisch A, Kinkhabwala M, Reinus J, Liu Q, Chuy JW (2017) Bridging therapy effectiveness in the treatment of hepatocellular carcinoma prior to orthotopic liver transplantation. J Gastrointest Oncol. 8(6):1051-1055

Samoylova ML, Dodge JL, Yao FY, Roberts JP (2014) Time to transplantation as a predictor of hepatocellular carcinoma recurrence after liver transplantation. Liver Transplant 20(8):937-944

San Miguel C, Vilchez A, Villegas T, Granero KM, Becerra A, Lopez MA et al (2015) Influence of waiting list in recurrence disease of hepatocellular carcinoma. Transpl Proc 47(9):2636-2638

Sapisochin G, Barry A, Doherty M, Fischer S, Goldaracena N, Rosales $R$ et al (2017) Stereotactic body radiotherapy vs TACE or RFA as a bridge to transplant in patients with hepatocellular carcinoma: an intention-to-treat analysis. J Hepatol 67(1):92-99

Seehofer D, Nebrig M, Denecke T, Kroencke T, Weichert W, Stockmann $\mathrm{M}$ et al (2012) Impact of neoadjuvant transarterial chemoembolization on tumor recurrence and patient survival after liver transplantation for hepatocellular carcinoma: a retrospective analysis. Clin Transpl 26(5):764-774

Shaker MK, Montasser IF, Sakr M, Elgharib M, Dabbous HM, Ebada $\mathrm{H}$ et al (2018) Efficacy of loco-regional treatment for hepatocellular carcinoma prior to living donor liver transplantation: a report from a single center in Egypt. J Hepatocell Carcinoma 5:29-36 
Vasnani R, Ginsburg M, Ahmed O, Doshi T, Hart J, Te H et al (2016) Radiofrequency and microwave ablation in combination with transarterial chemoembolization induce equivalent histopathologic coagulation necrosis in hepatocellular carcinoma patients bridged to liver transplantation. Hepatobiliary Surg Nutr 5(3):225-233

Yao FY, Kerlan RK Jr, Hirose R, Davern TJ 3rd, Bass NM, Feng S et al (2008) Excellent outcome following down-staging of hepatocellular carcinoma prior to liver transplantation: an intention-to-treat analysis. Hepatology 48(3):819-827
Yao FY, Mehta N, Flemming J, Dodge J, Hameed B, Fix O et al (2015) Downstaging of hepatocellular cancer before liver transplant: long-term outcome compared to tumors within Milan criteria. Hepatology 61(6):1968-1977

Publisher's Note Springer Nature remains neutral with regard to jurisdictional claims in published maps and institutional affiliations. 